\title{
Immunogenetic study of the response to streptococcal carbohydrate antigen of the cell wall in rheumatic fever
}

M Hafez, A Abdalla, F El-Shennawy, Y Al-Tonbary, A Sheaishaa, Z El-Morsi, Sh Tawfik, A Settien, M Abou El-Khair

\begin{abstract}
An immunogenetic study of the response to streptococcal carbohydrate antigen of the cell wall was carried out on members of 15 multiplex families each having more than one sib affected with rheumatic heart disease. They comprised 30 parents and 61 sibs ( 32 with rheumatic disease and 29 without). Fifty healthy unrelated subjects served as controls. A history was taken and clinical examination carried out. Rheumatic activity was determined and HLA typing was carried out for nine $A$ antigens, $15 \mathrm{~B}$ antigens, and six $\mathrm{DR}$ antigens. The immune response of lymphocytes to streptococcal polysaccharide antigen of the cell wall of group $A \beta$ haemolytic streptococci in vitro was studied by tritiated thymidine uptake. The results were statistically and genetically analysed. It was found that $(a)$ all subjects with rheumatic disease were highly responsive to the streptococcal polysaccharide antigen of the cell wall, the sib pairs being mostly HLA identical; $(b)$ all low responders had no rheumatic disease and their phenotypes were mostly different from those of the rheumatic member of their sib pair; (c) correlation of immune responsiveness (high or low) between HLA-identical sibs was significant, but insignificant between haplotype identical and non-identical sibs; $(d)$ the gene responsible for high responsiveness to the streptococcal polysaccharide antigen of the cell wall is recessive and closely linked to HLA. In conclusion, it was found that exposure to pharyngeal infection with group $A \beta$ haemolytic streptococci may lead to acute rheumatic fever in those with an inherited recessive gene responsible for high responsiveness to the streptococcal polysaccharide antigen of the cell wall.
\end{abstract}

Department of Pediatrics, and the Division of Immunology,

Department of Clinical Pathology, Faculty of Medicine, Mansoura

University, Mansoura,

Egypt

M Hafez

A Abdalla

F El-Shennawy

Y Al-Tonbary

A Sheaishaa

Z El-Morsi

Sh Tawfik

A Settien

M Abou El-Khair

Correspondence to:

Professor Mohammed Hafez,

Department of Pediatrics,

Faculty of Medicine,

University of Mansoura,

Mansoura, Egypt.

Accepted for publication

25 October 1989 genesis of acute rheumatic fever.

Numerous attempts have been made to show the existence of immune response genes or immune suppressor genes in man with a series of antigens, such as streptokinase and strepto-
Development of acute rheumatic fever, which is interaction, is generally thought to entail rehigh titres of antibodies against streptoco ponents of host tissues, and alterations of the response 24 all indicate dornase, ${ }^{5}$ influenza $A,{ }^{6}$ vaccinia, ${ }^{7}$ and tetanus toxoid. ${ }^{8}$ Sasazuki et al investigated the immune response to streptococcal cell wall antigen by the $T$ cell proliferation in vitro among the members of 23 healthy families. 9 They suggested a dominant gene for low responsiveness to streptococcal cell wall closely linked to HLA.

In this study we investigated the pattern of cellular immune response to the group A polysaccharide antigen of the streptococcal cell wall in vitro. To identify the HLA linked immune response or immune suppressor genes or the mode of inheritance, or both, family analysis is essential. Thus we studied the members of families having more than one sib affected with rheumatic heart disease. We aimed at clarifying the genetic control that may govern the immune response to this antigen and determining whether it is linked to the HLA region.

\section{Patients and methods}

The study was carried out on members of 15 multiplex families each having more than the one sib affected with rheumatic heart disease. They comprised 30 parents (two with rheumatic heart disease) and 61 sibs: 32 with rheumatic disease (13 male, 19 female, aged 6-26 years) and 29 without rheumatic disease (17 male, 12 female, aged 5-18 years). In only four families were the parents consanguineous (first cousins in family Nos 6, 9, 12 and first cousins once removed in family No 14). Only those sibs above the age of 5 years were included.

The rheumatic sibs were enrolled from the cardiac follow up outpatient clinic of the paediatric department of the University Hospital at Mansoura on the basis that the probands previously admitted to the hospital had been diagnosed as having acute rheumatic fever. None of the rheumatic patients was in heart failure or showed any clinical or laboratory evidence of rheumatic activity. For at least six months after complete clinical and laboratory improvement from the last attack of rheumatic activity they had received no treatment except long acting penicillin, and this was stopped one month before our investigations.

A detailed history was taken and clinical examination carried out on all the members of each family to exclude a past history suggestive of acute rheumatic fever or evidence of subclinical rheumatic heart disease or even recent streptococcal infection.

Fifty healthy unrelated subjects matched for age, sex, and socioeconomic standard served as a control group. They had been admitted to the 
hospital for minor surgical conditions. Neither they nor their first degree relatives had any history or clinical evidence of acute rheumatic fever or sequelae of rheumatic heart disease.

For all subjects included in the study the following investigations were carried out:

1 Clinical examination of all the probands and the living first degree relatives in the 15 multiplex families.

2 Detection of rheumatic activity, including erythrocyte sedimentation rate, $\mathrm{C}$ reactive protein, and antistreptolysin $\mathrm{O}$ titre to exclude recent streptococcal infection.

3 HLA antigen typing of the parents, affected, and unaffected sibs by standard complement dependent microlymphocytotoxicity testing. ${ }^{10}$ The following specificities were determined: locus $A: 1,2,3,9,10,11$, w19, 28 , 29; locus B: $5,7,8,12,13,14,15,16,17,18$, $21,22,27,37,40$; DR: 1, 2, 3, 4, 5, 7. The HLA antisera and rabbit complement were purchased from Hoechst-Behring Marburg, FRG.

4 Cellular immune response was examined in the peripheral blood lymphocytes in response to streptococcal polysaccharide antigen of the cell wall of group A $\beta$ haemolytic streptococci in vitro. The antigen had been extracted from 63 field strains of group $A \beta$ haemolytic streptococci obtained from throat culture surveys of a general population in the Qalyub area, near

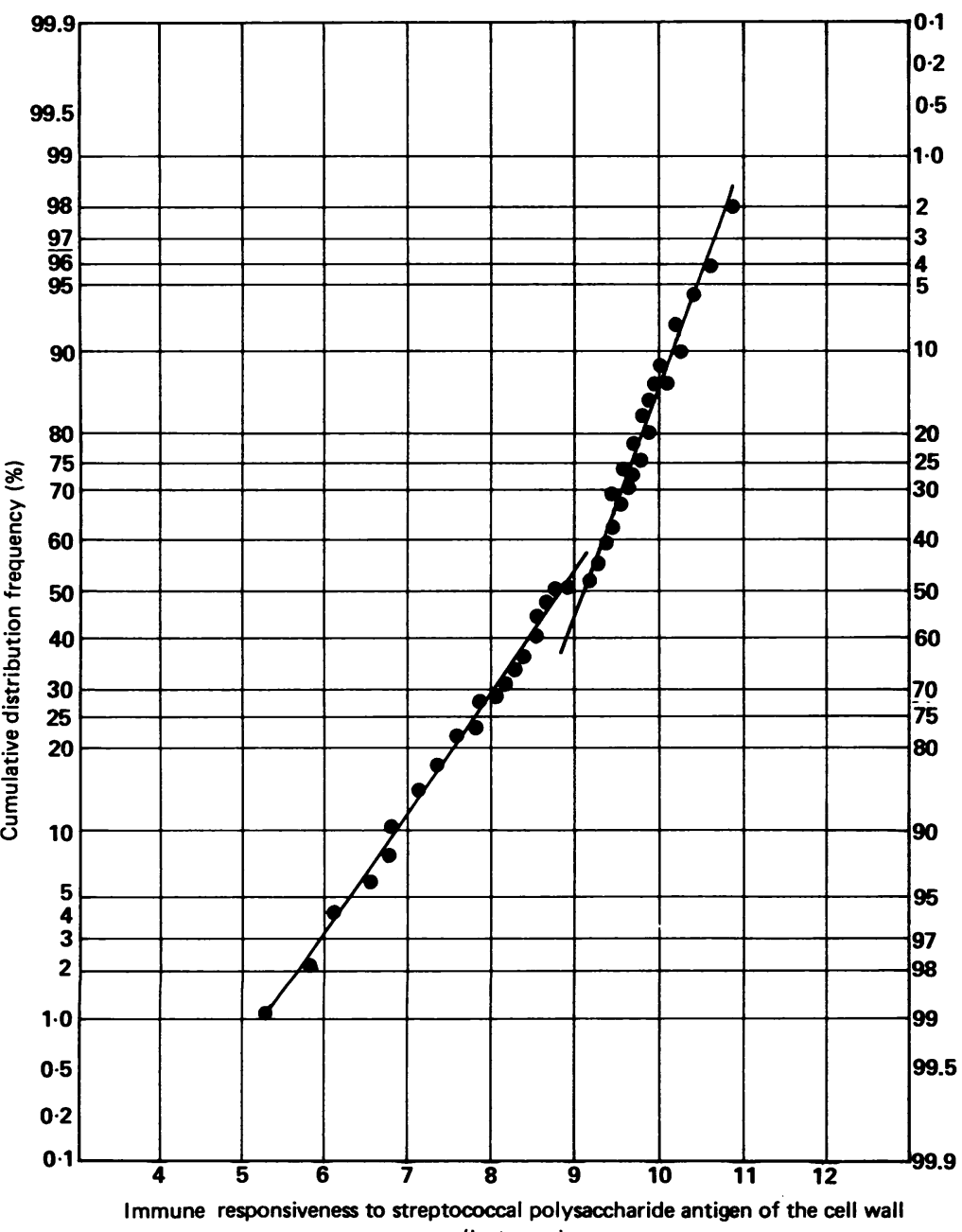

(In $\Delta \mathrm{cpm}$ )

Figure 1 Cumulative frequency for the immune response to the streptococcal polysaccharide antigen of the cell wall in the control group.
Cario, Egypt. ${ }^{11}$ The optimal antigenic dose was determined by chessboard titration in the blood of 10 patients with inactive rheumatic heart disease and in 10 normal subjects. The optimal dose thus determined was $0.275 \mu \mathrm{g} / \mathrm{ml}$ of lymphocytes. The lymphocytic count was adjusted to $2 \times 10^{6} / \mathrm{ml}$. To ensure that the method of culture was standardised the experiments on both control and study populations were performed simultaneously using phytohaemagglutinin and streptococcal cell wall antigen.

The effect of stimulation was studied by measuring DNA synthesis as indicated by $\left[{ }^{3} \mathrm{H}\right]$ thymidine uptake by the proliferating cells, ${ }^{12}$ which was measured as follows. $\left[{ }^{3} \mathrm{H}\right]$ Thymidine (37 kBq) with specific activity $74 \mathrm{MBq} / \mathrm{mmol}$ was added to the plates and incubated for 18 hours. Radioactivity was measured in a toluene based mixture by scintillation counting with a $\beta$ counter. The results were expressed as counts per minutes (cpm) in $2 \times 10^{6}$ lymphocytes and were the mean value for each sample studied in triplicate, before and after streptococcal mitogen response.

\section{STATISTICAL AND GENETIC ANALYSIS}

The goodness of fit for the mode of inheritance was obtained by the maximum likelihood scoring method $^{13}$ based on the probability of binomial distribution. The $\chi^{2}$ test was used to test for HLA haplotype concordance in the sib pairs. ${ }^{14}$ To test for correlation between HLA identical, haplotype identical and non-identical sibs, and the immune responsiveness to the streptococcal polysaccharide antigen of the cell wall, Spearman's rank correlation method was used. ${ }^{14}$ Finally, to test for linkage we used Morton's sequential linkage test and recombination fractions. ${ }^{1516}$ The method of the lods is based on likelihood, which is defined as the relative probability of finding a family with information on the two markers at various recombination fractions.

\section{Results}

The results of $\left[{ }^{3} \mathrm{H}\right]$ thymidine uptake by lymphocytes of the control group, expressed in natural logarithm counts per minute (ln $\Delta \mathrm{cpm}$ ), were analysed from the cumulative frequency curve drawn on normal probability paper (fig 1). The abscissa indicates the classes of the immune responsiveness expressed by $\ln \Delta \mathrm{cpm}$ and the ordinate indicates the cumulative distribution frequency (\%). The distribution showed a clear bimodality as represented by two independent lines with a cut off point at $9 \cdot 1$.

Table 1 Number (\%) of high and low responders among the members of the 15 multiplex families

\begin{tabular}{lrll}
\hline & $n$ & $\begin{array}{l}\text { High responders } \\
\text { No }(\%)\end{array}$ & $\begin{array}{l}\text { Low responders } \\
\text { No }(\%)\end{array}$ \\
\hline Parents: & 30 & $18(60)$ & $12(40)$ \\
$\quad$ Rheumatic & 2 & $2(100)$ & $0(0)$ \\
Non-rheumatic & 28 & $16(57)$ & $12(43)$ \\
Siblings: & 61 & $48(79)$ & $13(21)$ \\
$\quad$ Rheumatic & 32 & $32(100)$ & $0(0)$ \\
Non-rheumatic & 29 & $16(55)$ & $13(45)$ \\
\hline
\end{tabular}


Table 2 Summary of the observed phenotypes of immune responsiveness to the streptococcal polysaccharide antigen of the cell wall in the 15 families

\begin{tabular}{lll}
$\begin{array}{l}\text { Phenotypes of } \\
\text { parents }\end{array}$ & $\begin{array}{l}\text { Phenotypes of } \\
\text { children }\end{array}$ & $\begin{array}{l}\text { Number of } \\
\text { families }\end{array}$ \\
\hline $\mathrm{H} \times \mathrm{H}$ & H, H, H & 2 \\
& H, H, H, H & 4 \\
& H, H, H, H, H & 1 \\
$\mathrm{H} \times \mathrm{L}$ & H, H, H, H & 1 \\
& H, H, H, L & 1 \\
& H, H, H, L, L & 1 \\
& H, H, L, L, L & 1 \\
$\mathrm{~L} \times \mathrm{L}$ & H, H, L, & 1 \\
& H, H, L, L, & 2 \\
& H, H, H, L, L & 1 \\
\hline
\end{tabular}

$\mathrm{H}=$ high responder; $\mathrm{L}=$ low responder.
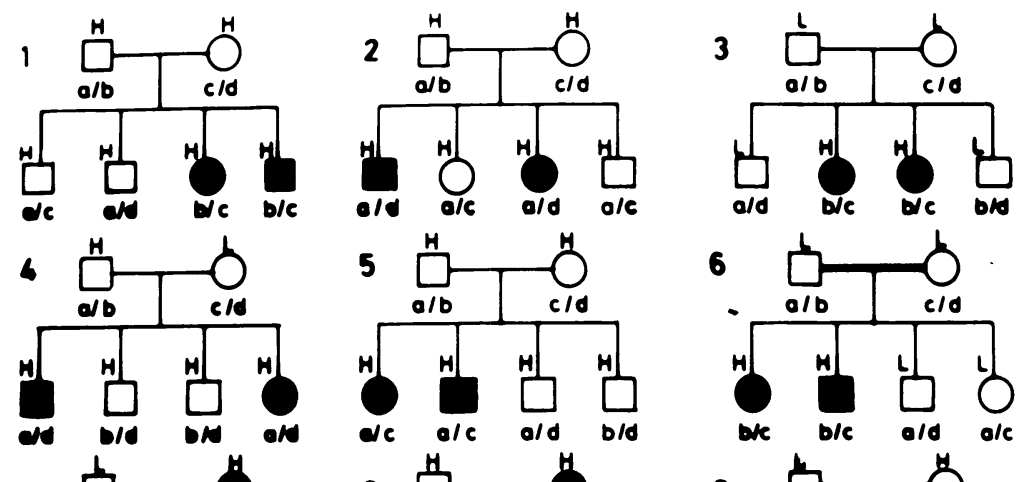

7

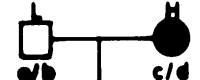

.
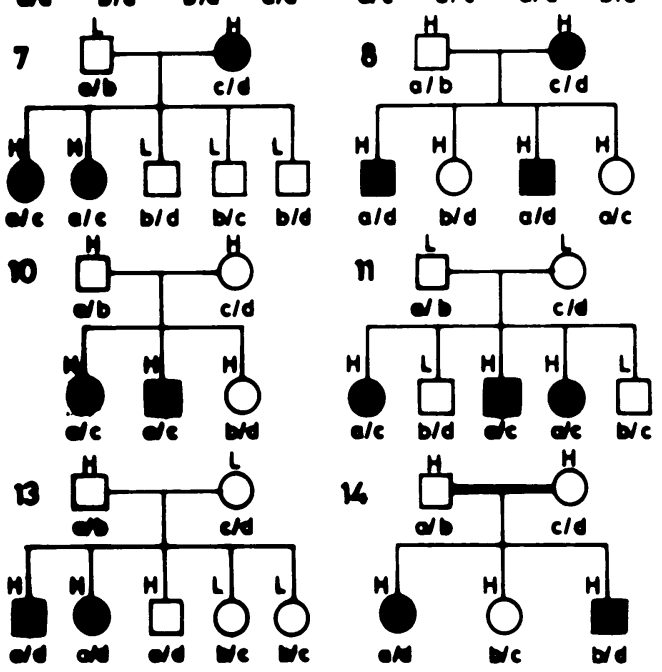

6
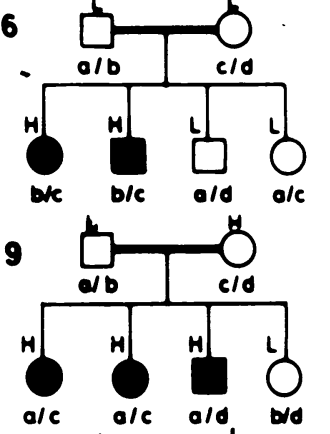

12

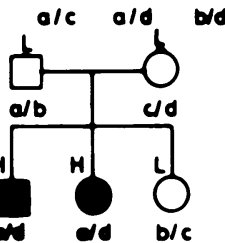

15

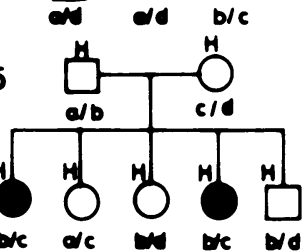

$\square \bigcirc$ Nermal

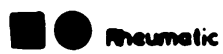

H: High responder to SPA - CW

L: Low responder to SPA - CW

a, b.c.d : Mepolypes of HLA

Figure 2 Pedigrees of the 15 families with the clinical presentation, the response to the streptococcal polysaccharide antigen of the cell wall $(S P A-C W)$, and HLA haplotypes assigned for each subject.

-Table 1 summarises the immune responsiveness of parents and siblings (rheumatic and non-rheumatic) of the 15 multiplex rheumatic families to the streptococcal polysaccharide antigen of the cell wall. Those above $9 \cdot 1 \ln \Delta$ cpm were considered high responders and those below this figure were considered low responders. Table 2 summarises the disposition, according to this criterion, of the high and low responders to the streptococcal polysaccharide antigen of the cell wall among the 15 families.

Figure 2 presents the pedigrees of the 15 families with the clinical presentation (rheumatic or non-rheumatic), the response to the streptococcal polysaccharide antigen of the cell wall, and HLA haplotypes assigned for each subject. Table 3 illustrates the HLA haplotypes of the parents as presented in the pedigrees.

The mode of inheritance for the immune responsiveness to the streptococcal polysaccharide antigen of the cell wall was analysed by the maximum likelihood scoring method, ${ }^{13}$ using only the eight informative families. All of these families were completely ascertained and penetrance of the gene controlling immune responsiveness to the streptococcal polysaccharide antigen of the cell wall was assumed to be complete. Four informative backcross families $(\mathrm{H} \times \mathrm{L})$ were analysed assuming that a single recessive gene controls the high responsiveness to the streptococcal polysaccharide antigen of the cell wall. There was no significant difference between the observed and expected results $(p>0.05)$, indicating that the hypothesis of a single recessive gene controlling high responsiveness to the streptococcal polysaccharide antigen of the cell wall cannot be rejected (table 4 ). This result was confirmed by the analysis of the four informative intercross families $(\mathrm{L} \times \mathrm{L})(\mathrm{p}>0.05)$ (table 5). Further support for this hypothesis comes from the observation that all siblings from matings of high responder parents were high responders. Because many high responder siblings were the result of mating of low responder parents, simple dominant inheritance for low responsiveness to the streptococcal polysaccharide antigen of the cell wall remains valid.

Table 6 illustrates the HLA haplotype concordance for rheumatic high responder sib pairs (group A), rheumatic and non-rheumatic high responder sib pairs (group B), and rheumatic and non-rheumatic low responder sib pairs

Table 3 HLA haplotypes of the parents in the 15 multiplex families

\begin{tabular}{|c|c|c|c|c|}
\hline \multirow{2}{*}{$\begin{array}{l}\text { Pedigree } \\
\text { No }\end{array}$} & \multicolumn{2}{|l|}{ Father } & \multicolumn{2}{|l|}{ Mother } \\
\hline & $a$ & $b$ & $c$ & $d$ \\
\hline 1 & $\mathrm{~A} 1, \mathrm{~B} 15, \mathrm{DR} 2$ & A11, B21, DR7 & $\mathrm{A} 2, \mathrm{~B} 18, \mathrm{DR} 1$ & $\mathrm{~A} 28, \mathrm{~B} 15, \mathrm{DR} 3$ \\
\hline 2 & Al1, B7, DR - & $\mathrm{A}-, \mathrm{B} 5, \mathrm{DR} 1$ & $\mathrm{~A} 2, \mathrm{~B} 17, \mathrm{DR} 2$ & Aw19, B12, DR \\
\hline 3 & $\mathrm{~A}-\mathrm{B} 12, \mathrm{DR} 4$ & $\mathrm{~A} 2, \mathrm{~B} 5, \mathrm{DR}-$ & A9, B27, DR1 & $\mathrm{B} 15, \mathrm{DR}$ \\
\hline 4 & $\mathrm{~A} 28, \mathrm{~B} 12, \mathrm{DR} 2$ & A1 $, \mathrm{B} 12, \mathrm{DR}$ & A9, B 18, DR3 & $\mathrm{B} 14, \mathrm{DR} 1$ \\
\hline 5 & $\mathrm{~A} 2, \mathrm{~B}-, \mathrm{DR} 1$ & $\mathrm{~A} 10, \mathrm{~B} 5, \mathrm{DR} 3$ & $\mathrm{~A} 2, \mathrm{~B} 12, \mathrm{DR} 3$ & B37, DR2 \\
\hline 6 & $\mathrm{~A} 3, \mathrm{~B} 18, \mathrm{DR}-$ & A9, B15, DR - & $\mathrm{A}-\mathrm{B} 5, \mathrm{DR} 4$ & $\mathrm{~B} 12, \mathrm{DR}-$ \\
\hline 7 & $\mathrm{~A}-, \mathrm{B} 40, \mathrm{DR} 2$ & $\mathrm{~A} 29, \mathrm{~B}-, \mathrm{DR} 1$ & $\mathrm{~A} 2, \mathrm{~B} 13, \mathrm{DR} 5$ & B37, DR - \\
\hline 8 & $\mathrm{~A} 1, \mathrm{~B} 5, \mathrm{DR} 3$ & A11, B12, DR3 & $\mathrm{A} 3, \mathrm{~B} 12, \mathrm{DR}$ & $\mathrm{B} 17, \mathrm{DR}$ \\
\hline 9 & A10, B8, DR - & $\mathrm{A} 10, \mathrm{~B} 14, \mathrm{DR} 2$ & Al, B15, DR 1 & B12, DR2 \\
\hline 10 & $\mathrm{Al}, \mathrm{B} 14, \mathrm{DR} 1$ & A2, B37, DR4 & $\mathrm{A} 2, \mathrm{~B} 17, \mathrm{DR}-$ & $\mathrm{B} 17, \mathrm{DR}$ \\
\hline 11 & $\mathrm{Al}, \mathrm{B} 17, \mathrm{DR} 4$ & $\mathrm{~A} 2, \mathrm{~B} 22, \mathrm{DR} 1$ & $\mathrm{~A} 2, \mathrm{~B} 5, \mathrm{DR} 3$ & $\mathrm{~B} 27, \mathrm{DR}-$ \\
\hline 12 & $\mathrm{~A} 2, \mathrm{~B} 12, \mathrm{DR}-$ & A11, B18, DR- & $\mathrm{A}-\mathrm{B} 22, \mathrm{DR} 1$ & B 14, DR 1 \\
\hline 13 & A10, B5, DR7 & A29, B15, DR I & $\mathrm{A} 2, \mathrm{~B} 5, \mathrm{DR}-$ & B8, DR3 \\
\hline 14 & $\mathrm{~A} 28, \mathrm{~B} 17, \mathrm{DR}-$ & A9, B40, DR3 & $\mathrm{A} 1, \mathrm{~B} 12, \mathrm{DR} 3$ & A28, B5, DR2 \\
\hline 15 & $\mathrm{Al}, \mathrm{B} 15, \mathrm{DR} 5$ & A2, B8, DR2 & A9, B17, DR2 & Aw19, B5, DR - \\
\hline
\end{tabular}


Table 4 Test for goodness of fit of the inheritance of imomume responsiveness to streptococcal polysaccharide antigen of the cell wall assuming an autosomal recessive inheritance for high responsiveness using backcross $(H \times L)$

\begin{tabular}{lllll}
\hline $\begin{array}{l}\text { No of } \\
\text { sibs }\end{array}$ & $\begin{array}{l}\text { Number of } \\
\text { high } \\
\text { responders }\end{array}$ & Observed & Expected & $\chi^{2}$ \\
\hline 4 & 1 & 0 & 0.54 & 0.54 \\
4 & 2 & 0 & 0.80 & 0.80 \\
4 & 3 & 1 & 0.54 & 0.39 \\
4 & 4 & 1 & 0.12 & 6.45 \\
5 & 1 & 0 & 0.32 & 0.32 \\
5 & 2 & 1 & 0.64 & 0.20 \\
5 & 3 & 1 & 0.64 & 0.20 \\
5 & 4 & 0 & 0.32 & 0.32 \\
5 & 5 & 0 & 0.08 & 0.08 \\
Total & & $4^{*}$ & $4.00^{*}$ & 9.3 \\
\hline *p $>0.05$ & & & &
\end{tabular}

Table 5 Test for goodness of fit of the inheritance of immune responsiveness to the streptococcal polysaccharide antigen of the cell wall assuming an autosomal recessive inheritance for high responsiveness using intercross $(L \times L)$

\begin{tabular}{lllll}
\hline $\begin{array}{l}\text { No of } \\
\text { sibs }\end{array}$ & $\begin{array}{l}\text { Number of } \\
\text { high } \\
\text { responders }\end{array}$ & Observed & Expected & $\chi^{2}$ \\
\hline 3 & 1 & 0 & 0.73 & 0.73 \\
3 & 2 & 1 & 0.24 & 2.41 \\
3 & 3 & 0 & 0.03 & 0.03 \\
4 & 1 & 0 & 0.24 & 1.24 \\
4 & 2 & 2 & 0.62 & 2.98 \\
4 & 3 & 0 & 0.12 & 0.12 \\
4 & 4 & 0 & 0.02 & 0.02 \\
5 & 1 & 0 & 0.52 & 0.52 \\
5 & 2 & 0 & 0.34 & 0.34 \\
5 & 3 & 1 & 0.12 & 6.45 \\
5 & 4 & 0 & 0.019 & 0.019 \\
5 & 5 & 0 & 0.001 & 0.001 \\
& & $4^{*}$ & $4.00^{*}$ & 14.86 \\
\hline
\end{tabular}

(group $C$ ). In groups $A$ and $C$ the values were significantly different from the expected $(p<0.001$ and $<0.01$ respectively). Group A was more associated with identical haplotypes, and group $\mathrm{C}$ with non-identical haplotypes. The disposition of haplotypes in group B tended towards association with identical haplotypes but this association was not significantly different from the expected value $(\mathrm{p}>0.05)$.

Table 7 shows the correlation of phenotypes of immune responsiveness to the streptococcal polysaccharide antigen of the cell wall between HLA identical, HLA haplotype identical, and HLA non-identical siblings. The correlation of the phenotypes of immune responsiveness $(\mathrm{H}$ or L) between HLA identical siblings was highly significant $(r=0.896 ; p<0.001)$, whereas for HLA haplotype identical and HLA nonidentical siblings the correlation was insignificant $(r=0.59 ; p>0.05$ and $r=0.32 ; p>0.05$ respectively).
Table 7 Correlation of the phenotypes of imomane responsiveness to the streptococcal polysaccharide antigen of the cell wall between (a) HLA identical siblings, (b) HLA haplonype identical siblings, (c) HLA non-identical siblings

\begin{tabular}{|c|c|c|c|}
\hline & $\begin{array}{l}\operatorname{Group}(a) \\
(n=12)\end{array}$ & $\begin{array}{l}\text { Group }(b) \\
(n=12)\end{array}$ & $\begin{array}{l}\text { Group }(c) \\
(n=10)\end{array}$ \\
\hline & \multicolumn{3}{|c|}{ Elder siblings } \\
\hline Younger siblings & $\begin{array}{lll} & \begin{array}{lll}H \\
H\end{array} \\
\text { H } 12 & 0 \\
\text { L } & 0 & 0\end{array}$ & 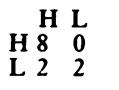 & $\begin{array}{lll} & H & \text { L } \\
\text { H } & 3 & 1 \\
\text { L } & 6 & 0\end{array}$ \\
\hline $\begin{array}{l}\mathrm{r}^{*} \\
\mathrm{p} \text { value }\end{array}$ & $\begin{array}{r}0.896 \\
<0.001\end{array}$ & $\begin{array}{l}0.590 \\
>0.05\end{array}$ & $\begin{array}{l}0.320 \\
>0.05\end{array}$ \\
\hline
\end{tabular}

Figures 3-5 illustrate the correlation of the immune response to the streptococcal polysaccharide antigen of the cell wall between HLA identical, HLA haplotype identical, and HLA non-identical sibs respectively. The abscissa indicates the immune response (ln $\Delta \mathrm{cpm}$ ) of the elder sibs and the ordinate indicates that of the younger sibs. The dotted lines indicate the cutoff point for low and high responsiveness.

Table 8 shows the lod scores for linkage between HLA and high response to the streptococcal polysaccharide antigen of the cell wall calculated with four informative families (Nos $4,7,9,13$ ) by Morton's sequential linkage tests. A maximum lod score $(4 \cdot 214)$ was obtained at $\theta=0.00$, indicating close linkage between HLA and high responsiveness to the streptococcal polysaccharide antigen of the cell wall.

\section{Discussion}

Four important findings have emerged from this study. Firstly, all subjects with rheumatic disease were highly responsive to the streptococcal polysaccharide antigen of the cell wall, the sib pairs being mostly HLA identical. Secondly, some sibs were high responders but did not have rheumatic fever. Sib pairs between these sibs and rheumatic sibs did not show a significantly different HLA phenotype concordance from that expected. Thirdly, all low responders had no rheumatic disease and their phenotypes were mostly different from those of the rheumatic member of their sib pair. Fourthly, the gene responsible for high responsiveness to the streptococcal polysaccharide antigen of the cell wall is recessive and closely linked to HLA.

The development of acute rheumatic fever and rheumatic heart disease is thought to be a result of a disturbance of immunological factors after infection by group $A \beta$ haemolytic streptococci. For example, patients with rheumatic

Table 6 HLA haplotype concordance for $(A)$ rheumatic high responder sib pairs, $(B)$ rheumatic and non-rheumatic high responder sib pairs, $(C)$ rheumatic and non-rhewomatic low responder sib pairs

\begin{tabular}{|c|c|c|c|c|c|c|}
\hline \multirow{2}{*}{$\begin{array}{l}\text { Concordant } \\
\text { haplotypes }\end{array}$} & \multicolumn{2}{|l|}{$A(n=25)$} & \multicolumn{2}{|l|}{$B(n=98)$} & \multicolumn{2}{|l|}{$C(n=94)$} \\
\hline & $\begin{array}{l}\text { Observed } \\
\%\end{array}$ & $\begin{array}{l}\text { Expected } \\
\%\end{array}$ & $\begin{array}{l}\text { Observed } \\
\%\end{array}$ & $\begin{array}{l}\text { Expected } \\
\%\end{array}$ & $\begin{array}{l}\text { Observed } \\
\%\end{array}$ & $\begin{array}{l}\text { Expected } \\
\%\end{array}$ \\
\hline $\begin{array}{l}2 \\
1 \\
0\end{array}$ & $\begin{array}{c}64(16)^{*} \\
36(9) \\
0(0)\end{array}$ & $\begin{array}{l}25 \\
50 \\
25\end{array}$ & $\begin{array}{l}29 \cdot 59(29) \\
48.98(48) \\
21.43(21)\end{array}$ & $\begin{array}{l}25 \\
50 \\
25\end{array}$ & $\begin{array}{l}19 \cdot 15(18) \\
34 \cdot 62(41) \\
37 \cdot 23(35)\end{array}$ & $\begin{array}{l}25 \\
50 \\
25\end{array}$ \\
\hline p Valuet & \multicolumn{2}{|c|}{$<0.001$} & \multicolumn{2}{|c|}{$>0.05$} & \multicolumn{2}{|c|}{$<0.01$} \\
\hline
\end{tabular}

${ }^{*}$ Number of pairs in parentheses.

$\mathrm{tx}^{2}$ Analysis. 
Table 8 Lod scores for linkage between HLA and high responsiveness to the streptococcal polysaccharide antigen of the cell wall calculated with four informative families by Morton's sequential linkage tests

\begin{tabular}{llllllllll}
\hline Family No & \multicolumn{2}{l}{ Recombination fraction $(\boldsymbol{\theta})$} \\
\cline { 2 - 10 } & 0.00 & 0.01 & 0.02 & 0.03 & 0.04 & 0.05 & 0.1 & 0.2 & 0.3 \\
\hline 4 & 0.903 & 0.886 & 0.868 & 0.850 & 0.832 & 0.814 & 0.720 & 0.517 & 0.298 \\
7 & 1.204 & 1.182 & 1.160 & 1.138 & 1.116 & 1.093 & 0.975 & 0.720 & 0.436 \\
9 & $\mathbf{0 . 9 0 3}$ & 0.886 & 0.886 & 0.850 & 0.832 & 0.814 & 0.720 & 0.517 & 0.298 \\
13 & 1.204 & 1.182 & 1.160 & 1.138 & 1.116 & 1.093 & 0.975 & 0.720 & 0.436 \\
Total & 4.214 & 4.136 & 4.056 & 3.976 & 3.896 & 3.814 & 3.390 & 2.474 & 1.468 \\
\hline
\end{tabular}

Figure 3 Correlation of the immune response to the streptococcal polysaccharide antigen of the cell wall between HLA identical sibs.

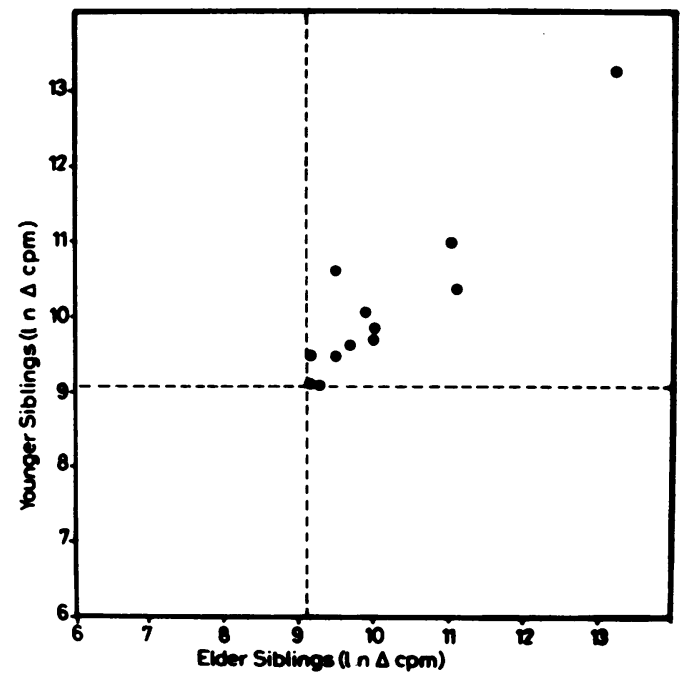

Figure 4 Correlation of the immune response to the streptococcal polysaccharide antigen of the cell wall between HLA haplotype identical sibs.

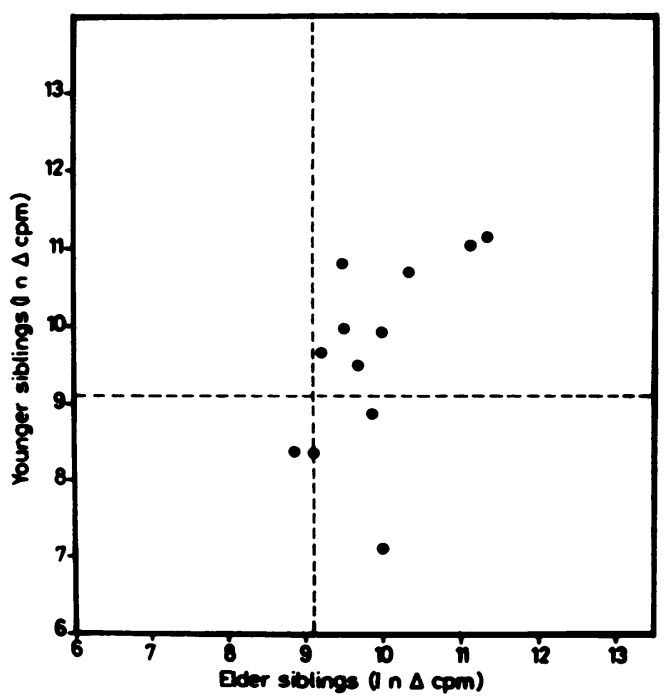

Figure 5 Correlation of the immune response to the streptococcal polysaccharide antigen of the cell wall between HLA non-identical sibs.

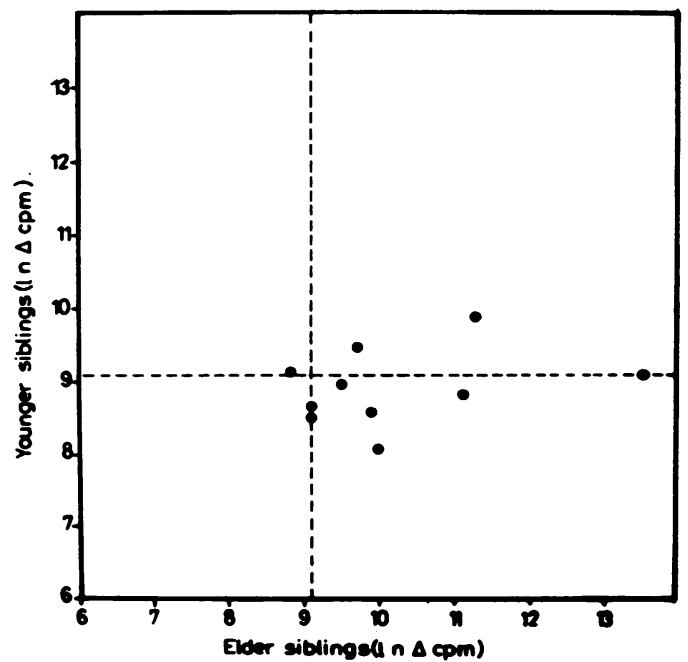

fever have a well recorded marked increase of antibodies to various streptococcal antigens compared with subjects without rheumatic fever. ${ }^{17}$ In addition, serum samples of patients with acute rheumatic fever contain antibodies that cross react with constituents of human cardiac tissues, whereas these antibodies are present in very low titres or absent in uncomplicated streptococcal infections. ${ }^{18} 19$

Several mitogens, streptococcal structures, and toxins were found to induce lymphoblastic transformation in vitro. Some workers used phytohaemagglutinin and Candida albicans as non-specific mitogens and they found decreased lymphocyte transformation among rheumatic patients, especially during rheumatic activity. ${ }^{2} 420-22$ This hyporesponsiveness was attributed to possible reactions during the active stage of the disease. Similar results have been obtained by using streptococcal extracellular products and toxins. ${ }^{21-24}$

Goldstein et al reported that mammalian structural glycoproteins obtained from heart valves contain antigens similar to those isolated from group A streptococcal cell walls. ${ }^{25}$ The shared antigenicity seemed to be due to the presence of common $N$-acetylglucosamine terminal groups in mammalian tissue and the group A streptococcal carbohydrate. This group-specific carbohydrate antigen accounts for about $30-50 \%$ of the dry weight of the cell wall and about $10 \%$ of the intact cell. Dudding and Ayoub noted that serum samples from patients who develop rheumatic valvular disease contain high titres of antibodies to the streptococcal group A carbohydrate and that these antibodies may persist for years after the initial attack. ${ }^{26}$ This antibody is probably the result rather than the cause of tissue injury, however. ${ }^{27}$

In view of these previous findings we decided to study the pattern of cellular immune response to this particular cell wall antigen, especially as there are no reports dealing either with the cellular immune response or the possible genetic control that may govern such response to this particular antigen in rheumatic patients.

The cellular immune response of our control population to the streptococcal polysaccharide antigen of the cell wall showed a cut-off point at $9 \cdot 1 \ln \Delta \mathrm{cpm}$. A study of a normal Japanese population using the whole streptococcal cell wall antigen showed a cut-off point at $9.6 \ln \Delta$ cpm. ${ }^{9}$ This small difference might be attributed to: firstly, the difference in the procedure of extraction of the antigen-we used the method described by El-Kholy et $a^{11}$ and the Japanese group used that described by Sasazuki et al. ${ }^{28}$ Secondly, the optimum antigenic dose was 
different-we used the streptococcal polysaccharide antigen of the cell wall, whereas the Japanese used the whole streptococcal cell wall antigen.

A study of the mode of inheritance for immune responsiveness to the streptococcal polysaccharide antigen of the cell wall was carried out by the maximum likelihood scoring method using only the eight informative families $(H \times L$ and $L \times L)$, and assuming that the gene controlling high responsiveness to streptococcal polysaccharide antigen of the cell wall was a recessive one and its penetrance was complete. Analysis of the results showed that the hypothesis of a single recessive gene for high responsiveness to the streptococcal polysaccharide antigen of the cell wall cannot be rejected. Confirmation for this comes from the observation that all sibs resulting from matings of high responder parents were almost always high responders. On the other hand, because some high responder siblings were obtained from the mating of low responders, a simple dominant inheritance for low responsiveness to the streptococcal polysaccharide antigen of the cell wall might be possible. Similar results have been reported by Sasazuki et al among normal Japanese families. ${ }^{9}$

Screening of the pedigrees showed that all the subjects with rheumatic disease were high responders, and all the low responders had no rheumatic disease. This is contrary to the results of Reed $e t$ al, who studied the cellular reactivity to streptococcal group A carbohydrate antigen among patients with inactive rheumatic fever with and without valvular diseases and compared the results with the response to streptococcal membrane antigens. ${ }^{29}$ They found no significant difference and attributed such results to the limited range of antigen concentration used.

Correlations between elder and younger sibs for the concordance of HLA haplotypes in relation to the immune response to the streptococcal polysaccharide antigen of the cell wall indicate clearly that the gene responsible for the immune response is within the HLA region. Thus the major histocompatibility complex plays a crucial part in controlling the immune response to the streptococcal polysaccharide antigen of the cell wall. Furthermore, analysis of HLA haplotype concordance highlighted some important points: firstly, the results for groups $\mathrm{A}$ and $\mathrm{C}$ (table 6 ) indicate that the high responsiveness to the streptococcal polysaccharide antigen of the cell wall is an important component in the multifactorial genetic variance forming the susceptibility to acute rheumatic fever. Secondly, the high incidence of HLAidentical rheumatic sib pairs, which means homozygosity, confirms a recessive character. Thirdly, the results for group B (table 6) might be due to the effect of other gene(s) closely associated with HLA and concerned in the pathogenesis of acute rheumatic fever. ${ }^{3} 430$

An earlier report showed a genetic linkage between the blastogenic response to streptococcal cell wall preparation and the HLA region. ${ }^{31}$ Also, the magnitude of the antibody response to group A carbohydrate that is produced in laboratory animals was proved to be genetically controlled. ${ }^{32}$ This was recently confirmed by Ayoub et al, who reported an association between increased antibody production to group A carbohydrate antigen and a particular HLA class II antigen (DR2 and DR4). ${ }^{33}$ In our study, however, an analysis of the association between HLA and the recessive gene for high responsiveness to the streptococcal polysaccharide antigen of the cell wall by recombination fractions showed very close linkage, as indicated by the higher lod scores obtained at $\theta=0.001$ and 0.01 .

Thus pharyngeal infection with group A $\beta$ haemolytic streptococci of sufficient virulence and antigenicity might produce acute rheumatic fever and rheumatic heart disease in those subjects with inherited recessive gene responsible for high responsiveness to the streptococcal polysaccharide antigen of the cell wall. The presence of other polygenes that provide the special genetic make up and susceptibility to acute rheumatic fever would probably also be necessary.

The lyophilised streptococcal carbohydrate antigen of the cell wall was a gift from the American-Egyptian study group on acute rheumatic fever at the University of Minnesota, Minneapolis, Minnesota, USA.

1 Zabriskie J B, Read S E, Ellis R J. Cellular and humoral studies in diseases with heart reactive antibodies. In: Bernard A, ed. Progress of immunology. New York: Academic Press, 1971: 213-29.

2 Meric N, Berkel A I. Cellular immunity in children with acute rheumatic fever and rheumatic carditis. Pediatr Res 1979; 131: 16-20.

3 Hafez M, El-Shennawy F, El-Ziny M, Abo-Elhassan S, Khashaba $M$. Presumptive evidence for an immunoKhashaba $M$. Presumptive evidence for an immunofuppressor susceptibility gene linke

4 Hafez M, El-Shennawy F, El-Sallab Sh, et al. Studies of peripheral blood lymphocytes in assessment of disease activity in rheumatic fever. $\mathrm{Br} \mathcal{F}$ Rheumatol 1988; 27: $181-6$

5 Greenberg L J, Bradley P W, Chopyk R L, Lalovel J M. Immunogenetics of response to a purified antigen from group A streptococci. II. Linkage of response to HLA. Immunogenetics 1980; 11: 161-7.

6 Spencer M J, Cherry J D, Terasaki P I. HLA antigens and antibody response after influenza $A$ vaccination. Decreased response associated with HLA type W16. N Engl F Med 1976; 294: 13-16.

7 De Vries R R P, Kreeftenberg H G, Loggen H G, van Rood $J$ J. In vitro immune responsiveness to vaccinia virus and JLA. $N$ Engl f Med 1977; 297: 692-6.

8 Sasazuki T, Kohno Y, Iwamoto I, Tanimura M, Naito S. Association between an HLA haplotype and low responsiveness to tetanus toxoid in man. Nature 1978; 273: 359-60.

9 Sasazuki T, Nishimura Y, Muto M, Ohta N. HLA-linked genes controlling immune response and disease susceptibility. Immunol Rev 1983; 70: 59-74.

10 Kissmeyer-Nielson F, Dick H M. Lymphocyte cytotoxicity testing. In: Dick H M, Kissmeyer-Nielson, eds. Histo compatibility techniques. 1st ed. Amsterdam: Elsevier-North compatibility techn

11 El-Kholy A, Wannamaker L W, Krause R M. Simplified extraction procedure for serological grouping of betaextraction procedure for serological grouping of beta-

12 Sapru R P, Ganguly N K, Sharma S, Chandani R E, Gupta A $K$. Cellular reaction to group A $\beta$-haemolytic streptococcal membrane antigen and its relation to complement levels in patients with rheumatic heart disease. Br Med $\mathcal{J}$ 1977; ii: $422-4$.

13 Morton N E. Genetic tests under incomplete ascertainment. Am F Hum Genet 1959; 11: 1-16.

4 Armitage P. Statistical methods in medical research, 5th ed. New York: Wiley, 1983

15 Morton N E. Further scoring types in sequential linkage tests, with a critical review of autosomal and partial sex linkage in man. Am 7 Hum Genet 1957; 9: 55-75.

16 Emery A E. Methodologies in medical genetics. 4th ed. London, Oxford, Edinburgh: Churchill Livingstone, 1976.

Stollerman $\mathrm{G} \mathrm{H}$. Rheumatic fever and streptococcal infection. Vol 8. 1st ed. New York: Grune and Stratton, 1975: 181.

18 Kaplan M H, Meyeserian M, Kushner I. Immunologic studies of heart tissue: IV Serologic reactions with human studies of heart tissue: IV Serologic reactions with human 
isoimmune, Wassermann and autoimmune reactions. f Exp Med 1961; 113: 17-36.

19 Zabriskie J B, Hsu K C, Seegal B C. Heart reactive antibody associated with rheumatic fever: characterisation and diagnostic significance. Clin Exp Immumol 1970; 7: 147-59.

20 Oppen stimulation by some streptococcal antigens in then stimulation by some streptococcal antigens in rheumatic heart disease. Foumal of

21 Cuppari G, Quagliata F, Ieri A, Taranta A. Lymphocytic transformation with streptolysin S preparations and inhibition of streptolysin S by serum in rheumatic fever and othe rheumatic diseases. F Lab Clin Med 1972; 80: 165-78.

22 Gray E D, Wannamaker L W, Ayoub E M, El-Kholy A Abdin Z. Cellular immune responses to extracellular streptococcal products in rheumatic heart disease. $\mathcal{f}$ Clin Invest 1981; 68: 665-71.

23 Hirschhorn K, Schreibman R R, Verbo S, Gruskin R H. The action of streptolysin $S$ on peripheral lymphocytes of normal subjects and patients with acute rheumatic fever. Proc Natl Acad Sci USA 1964; 52: 1151-7.

24 Rich S S, Gray E D, Talbot R, et al. Cell surface markers and cellular immune response associated with rheumatic heart disease: complex segregation analysis. Genet Epidemiol disease: complex

25 Goldstein I, Rebeyrotte P, Parlebas J, Halpern B. Isolation from heart valves of glycopeptides which share immunological properties with streptococcus haemolyticus group A polysaccharides. Nature 1968; 219: 866-8.
26 Dudding B A, Ayoub E M. Persistence of streptococcal group A antibody in patients with rheumatic valvular disease. F Exp Med 1968; 128: 1081-98.

27 Stollerman G H. Rheumatic fever. In: William N K, Edward D H Jr, Shaun R, Clement B S, eds. Textbook of rheumatology. Vol II. 2nd ed.

28 Sasazuki T, Ohta N, Kaneoka R, Kajima S. Association between an HLA haplotype and low responsiveness to schistosomal worm antigen in man. $\mathcal{J}$ Exp Med 1980; 152: $314-8$.

29 Reed S E, Fischetti V H, Utermohlen V, Falk R E, Zabriskie J B. Cellular activity studies to streptococcal infections and rheumatic fever. $\mathcal{f}$ Clin Invest 1974; 54: 439-50.

$30 \mathrm{Hafez}$ M, El-Battoty M F, Hawas S, et al. Evidence of inherited susceptibility of increased streptococcal adherence to pharyngeal cells of children with rheumatic fever. Brf Rheumatol 1989; 28: 304-9.

31 Sasazuki T, Kaneoka H, Nishimura Y, Kaneoka R, Hayama $M$, Ohkani H. An HLA-linked immune suppression gene in man. F Exp Med 1980; 152: 297-313.

32 Eichmann $K$, Kindt $T J$. The inheritance of individual antigenic specificities of rabbit antibodies to streptococcal antigenic specificities of rabbit antibodies to stre

33 Ayoub E M, Barrett D J, Maclaren N K, Krischer J P. Association of class II human histocompatibility leukocyte antigens with rheumatic fever. F Clin Invest 1987; 77: 2019-26. 